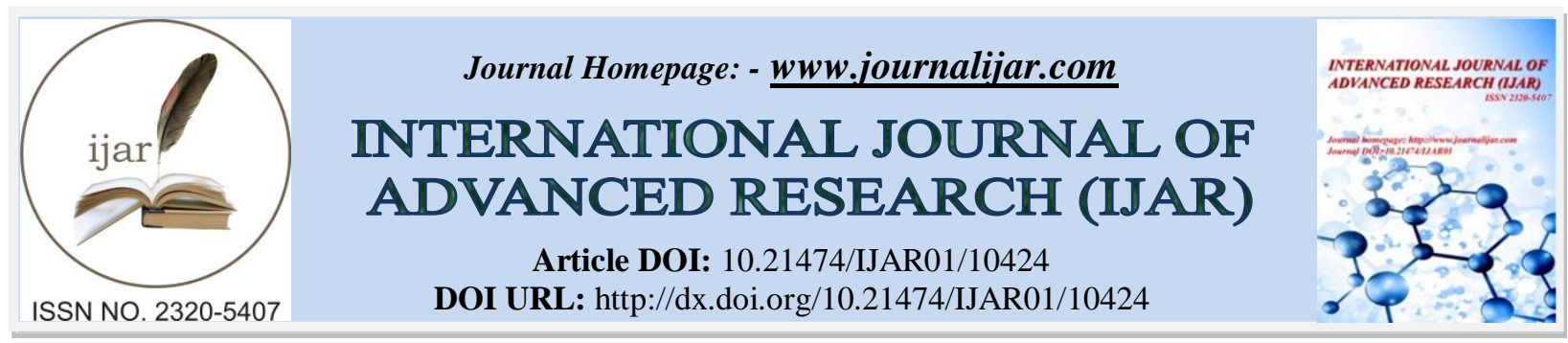

RESEARCH ARTICLE

\title{
NATURAL RESOURCE MANAGEMENT IN THE WELFARE STATE PARADIGM ON THE ENVIRONMENTAL POLICY RULES IN INDONESIA
}

Fatma Ulfatun Najicha, I Gusti Ayu Ketut Rachmi Handayani, Hartiwiningsih and Lego Karjoko Faculty of Law, Universitas Sebelas Maret, Surakarta, Indonesia.

\section{Manuscript Info}

Manuscript History

Received: 30 November 2019

Final Accepted: 31 December 2019

Published: January 2020

Key words:-

Management, Natural Resources,

Paradigm, Environmental Policy

\begin{abstract}
Management of natural resources in Indonesia can be stated that all countries in principle have the same goal namely, providing welfare for its citizens. Likewise Indonesia. The purpose of the Republic of Indonesia as contained in the Preamble to the 1945 Constitution is to advance public welfare, improve the life of the nation or in other formulations to realize social justice for all Indonesian people. The results of the discussion explained that: constitutionally the Republic of Indonesia is a follower of the welfare state paradigm. The state proactively and imperatively participates in seeking justice and social welfare for all people. As a sovereign nation, the Republic of Indonesia has a very broad role to regulate all aspects of life in order to create the greatest prosperity of the people without any interference from any country. Sovereignty or sovereignty is one of the requirements for the establishment of a country. One element of the state is the existence of a sovereign government, the Government in a country must have the supreme authority (supreme) and unlimited (unlimited).
\end{abstract}

Copy Right, IJAR, 2020,. All rights reserved.

\section{Introduction:-}

Environmental laws are made with the aim of protecting the environment and providing benefits to the community. In other words, there must be legal certainty in it. In the development of environmental law, legal certainty is needed because legal certainty requires how the law is implemented, regardless of how bitter (fiat justitia et pereat mundus: even though the world collapses the law must be upheld). This is intended to create order in society. For example: "Anyone who pollutes the environment must be punished", this provision requires that anyone (no matter their position) if polluting the environment must be punished. It should be remembered that the punishment of pollutants here is not because they pollute (so it is not based on cause and effect), but because of an existing regulation that prohibits such acts of pollution. That is what is desired in legal certainty, what is the sound of the law that is carried out. Instead the community wants benefits in the implementation of environmental regulations or law enforcement.

Environmental law is made with the aim of protecting the environment and providing benefits to the community. This means that the regulation is made for the benefit of the community, so that it does not happen that, because of the implementation of the regulation, the community will actually be restless. Example: a convection factory that employs thousands of people is closed because it has polluted the environment, this will certainly cause unrest for both the business community and its workers. Why not look for other solutions, such as dragging the management of the company to court, obliging companies to pay for environmental recovery, but factory activities continue to run under strict supervision along with reduced production. This is called the usefulness in environmental law 
enforcement. The third element is justice. In environmental law enforcement, justice must be considered. However, the law is not synonymous with justice, because the law is general in nature, binding everyone, and generalizing; reads the law: "anyone who pollutes the environment must be punished," meaning that anyone who pollutes the environment must be punished, regardless of the position or position of the person who is polluting. But on the contrary, justice is subjective, individualistic, and not generalized, meaning that being fair for the A is not necessarily fair for the B, the polluter won will say that the decision is fair, but it certainly feels unfair to the victim. From the description above it can be concluded, that without legal certainty people do not know what to do and finally anxiety arises. However, if we pursue legal certainty, too strict in obeying the rule of law, the result will be rigid and will cause a feeling of injustice. The law feels cruel if it is carried out strictly: lex dura, sed tamen script (the law is cruel, but indeed it sounds).

According to Merto Kusumo, in law enforcement only legal certainty is concerned, then the other elements are sacrificed. Likewise, if what is concerned is only benefit, then certainty and justice are sacrificed, and so on. Therefore, in the enforcement of these three legal environments, certainty, expediency, and justice must be compromised. This means that the three must get proportionally balanced attention in handling it, even though in practice it is not always easy to do it.

From the above review it can be seen that the Management of Natural Resources in the Welfare State Paradigm (welfare state) in the regulation of environmental policies in Indonesia is a human rights and constitutional rights for every Indonesian citizen. By carrying out environmental protection and management in carrying out sustainable development so that the Indonesian environment can remain a source and support for the people of Indonesia and other living things.

\section{Research Method:-}

This type of research is normative legal research, which is conducted to find solutions to legal problems, so the results of this study are conducted to provide a prescription of what should be about the problems raised and can be applied in legal practice. The approaches used in this study include the statute approach, the conceptual approach, and the analytical approach.

The statute approach is carried out by examining all laws and regulations relating to the legal issues being studied. Researchers need to look for legis ratios and the ontological basis for the birth of laws on natural resource management both oil and gas and minerals. capturing the philosophical content that is behind it. Understanding the philosophical content behind the law, will be able to conclude whether or not there is a philosophical conflict between the law and the issues at hand.

The conceptual approach moves from the views and doctrines that develop in the science of law. With the conceptual approach (conceptual approach), researchers will find ideas that give birth to legal notions, legal concepts, and legal principles that are relevant to the issue at hand. Understanding of these views and doctrines is the basis for researchers in developing a legal argument in solving the issues at hand.

The analytical approach (analitical approach) is useful for interpreting logically, systemically and consistently where a more detailed and in-depth study of data is collected. Secondary data collected in this study is processed, analyzed and concluded conclusions using a judicial jurisdiction method.

\section{Findings And Discussion:-}

Theoretically, natural resource management in Indonesia can be stated that all countries in principle have the same goal, namely, to provide welfare for its citizens. Likewise Indonesia. The purpose of the Republic of Indonesia as contained in the Preamble to the 1945 Constitution is to advance public welfare, improve the life of the nation or in other formulations to realize social justice for all Indonesian people. Such formulation emphasizes that constitutionally the Republic of Indonesia is a follower of the welfare state paradigm. The state proactively and imperatively participates in seeking justice and social welfare for all people. As a sovereign nation, the Republic of Indonesia has a very broad role to regulate all aspects of life in order to create the greatest prosperity of the people without any interference from any country. Sovereignty or sovereignty is one of the requirements for the establishment of a country. One element of the state is the existence of a sovereign government, the Government in a country must have the supreme authority (supreme) and unlimited (unlimited). 
Sovereignty which refers to the full independence of a country that has the highest authority both inside and outside, and therefore the state is the highest creator of the rule of law for its people, for the first time stated by Jean Bodin in his book Six Livres de la Republique (1576). The main characteristic of state sovereignty according to Jean Bodin is the power to determine the law for citizens, in general or one by one. In his view, sovereignty is not fragmented, original and perfect or unlimited. Not fragmented because in a country there is only a supreme power. Original because the highest power does not come from a higher and unlimited power because there is no higher power that can limit that power. Next to talk about the concept of the highest power which is commonly called sovereignty in general is associated with notions that develop in history, one after the other. However, it can be concluded that the history of humanity's understanding of the highest authority or sovereignty includes five conceptions, namely: Theory of God's Attitude; King's Sovereignty Theory; The rule of law sovereignty; Theory of People's Sovereignty; and State Sovereignty Theory.

Indonesian sovereignty as an independent state is formulated in the 1945 Constitution which combines the concepts of popular sovereignty, legal sovereignty and God's sovereignty at the same time.. $\quad$.. Article 1 paragraph (2) states, "Sovereignty is in the hands of the people and implemented according to the constitution". This provision reflects that the 1945 Constitution adheres to the sovereignty of the people or democracy based on the constitution or "constitutional democracy". While Article 1 paragraph (3) confirms, "The State of Indonesia is a state of law". This is what is meant by understanding the rule of law which basically adheres to the principle of the rule of law. But along with that, the idea of God's sovereignty is also recognized in the 1945 Constitution.

First, the Preamble to the 1945 Constitution recognizes that Indonesia's struggle for independence can succeed "By the blessing of Allah's Almighty Grace ..."; Second, the Preamble to the 1945 Constitution also states that "independence ... the Republic of Indonesia sovereignty of the people based on the Almighty God, ..."; Third, Article 9 paragraphs (1) and (2) of the 1945 Constitution stipulate that before assuming his position each President and / or Vice President is required to swear or promise by stating "By Allah" (for oath).

Then in the 1945 Constitution, sovereignty as the highest concept of power has not only political significance, but also economic and social significance. Chapter XIV of the 1945 Constitution is deliberately given the title "National Economy and Social Welfare". Inside there are provisions of Article 33, for example, in paragraph (3) emphasizing that, "The earth and water and the natural resources contained therein are controlled by the state and used for the greatest prosperity of the people". Article 33 paragraph (2) also confirms that, "Production branches which are important for the state and which control the livelihoods of the public are controlled by the state" The Indonesian state as a representation of its citizens must truly represent the interests of all people who have the highest sovereignty or power over the economic resources of Indonesia's natural wealth. Meanwhile according to J.J. Rousseau, the power of the state as a body or organization of the people is sourced from the results of the community agreement which is essentially a form of unity that defends and protects the joint power, personal power and property of each individual.

In accordance with the two theories above, then theoretically state power over natural resources comes from the people known as the nation. The state in this case is seen as having the character as an institution of the general public, so that it is given the authority or power to regulate, manage and maintain (supervise) the use of all potential natural resources that exist in its territory intensively. In the case of authority or power to regulate, manage and maintain (supervise) the utilization of all potential natural resources, it is stated in the form of legal politics. The political politics of managing natural resources both oil and gas and Indonesian Minerba are "constituting the attitude and / or attention of the Government / state to the management of Oil and Gas / Minerba in the form of policies as outlined in the Laws and Government Regulations, where the state's right to control over resources nature as the main and most basic foundation, its implementation by the state for the purpose of the greatest prosperity of the people".

In the management of natural resources, the State must consider the generational justice in drafting regulations governing the management of natural resources, in the sense that the wealth of natural resources utilized must pay attention to the carrying capacity of nature and benefits in the context of preserving nature for the benefit of the next generation. Principles in natural resource management (SDA) pay attention to and consider the principle of conservation, natural resources may be managed but do not cause damage and environmental pollution. The carrying capacity of nature is the main consideration for the realization of generational justice in the utilization of natural resources. Utilization and management of the environment, especially natural resources, should pay attention to the natural ecosystem (internal ecosystem) and artificial ecosystem (artificial ecosystem). This is so the development process or the process of utilizing natural resources in accordance with environmentally sound development. 
Important components that form the foundation of the development of the legal and political foundation of natural resource management consist of: a) Ownership of Natural Resources; b) Control by the State; and c) The authority of State Enterprises in the exploitation of natural resources up to the principle of cooperation with third parties (primarily with foreign parties including the limits of authority granted to foreign parties).

Ownership of natural resource wealth is subject to mining legal arrangements known as Mineral Rights, Mining Rights and Economic Rights. Mineral Authority is the State's control of natural resources contained in an area of the country as an integral part of. Regional sovereignty; Mining Authority is the authority in the regulation and supervision of the implementation of mining activities; and Mining Business Authority is the authority to control and manage the business.

The principle of the state's right to control over its natural resources is also recognized in international law as follows:

UN General Assembly Resolution, 21 December 1952 on the principle of self-determination in the economic field of each country (economic self-determination) which affirms the right of each country to freely utilize its natural resources.

Resolutions of the United Nations General Assembly, 14 December 1962, 25 November 1966 and 17 December 1973 which expanded the scope of the principle of permanent sovereignty over natural resources on the seabed and the subordinate lands and in sea waters which are still under national jurisdiction a country.

UN General Assembly Resolution of 1974 and the Declaration on the establishment of the New Indonesian Economic Order and the Charter of Economic Rights and Duties of State in 1974 reaffirmed the right of control of the state to monitor its natural resources in order to increase growth the economy.

Covenant on Economic, Social and Cultural Rights (Article 1) and Covenant and Civil Political Right (Article 1) dated December 16, 1966 affirm the right of a country to freely utilize its natural resources.

Furthermore, the political policy rearrangement of national natural resource management must be consistent and consistent with the direction of the 1945 Constitution as described above, on the basis that natural resources are strategic resources and have a very important function to build a just and prosperous society, constituting national wealth which is only undertaken by the state and its exploitation is only carried out by state enterprises. And if there is cooperation with third parties (national / foreign), its status is only as a contractor for state enterprises, because only through the management of state-owned enterprises, the effort to support the realization of prosperity can be realized. Then in addition to the foundation as stated above, there are various arrangements that must be considered in the preparation, namely:

That the mining industry, both Oil and Gas and Minerba, are important production branches for the country and control the livelihoods of any people directly or indirectly;

That Oil and Gas and Minerba has special meaning for national defense;

That the problems concerning Oil and Gas and Minerba contain international aspects;

That the right to control by the state must be in accordance with the objectives of the Welfare State as directed by the 1945 Constitution, Article 33 paragraph (3). The connection with the state's right to control with the greatest prosperity of the people will realize the state's obligation, among others, the main thing is that all forms of natural resource utilization must significantly increase prosperity and welfare.

That the management of oil and gas natural resources and mineral resources must be developed in the best interests of the national interest, as stated in the development law theory Mochtar Kusumaatmadja that in legal development there are neutral and not neutral laws. With regard to the management of Oil and Gas and Minerba, the authors are of the neutral legal category, thus to get the best, they can make comparisons with the concepts / policies of Oil and Gas and Minerba management in various countries without leaving the values contained in national identity. 


\section{Conclusion:-}

With the legal basis of legal management of oil and gas and mineral resources as described above, the author believes that immediate concrete steps must be taken to reconceptualize mining laws and regulations which have the mission of increasing national independence and resilience in order to be able to support sustainable national development. To realize this mission, future mining legislation needs to be supported by "five pillars", namely:

\section{Pancasila:}

Aside from being a national and state philosophy, Pancasila which is the source of all legal sources, must be used as a reference for every policy step related to natural resource management in Indonesia.

\section{The 1945 Constitution of the Republic of Indonesia:}

Basically, the laws and regulations concerning the management of natural resources must "return to the 1945 Constitution" and more specifically implement the spirit and soul contained in Article 33 consistently and consistently; that the management of natural resources can never be separated from social meaning. Politics and economics which means prosperity for all Indonesian people.

\section{Unitary State of the Republic of Indonesia (NKRI):}

Understanding the island nation with the motto "Unity in Diversity" which means "Unity in Diversity". In order for this motto not only contains the determination of national unity, but also is a "commitment" to all components of the nation carry out development for the creation of the Welfare State.

\section{Political alignments of the Government of the Republic of Indonesia:}

The political partisanship of the Government of the Republic of Indonesia is intended to be aimed at State Enterprises (SOEs) in the form of providing opportunities to become large and strong so that they can carry out their functions in providing long-term national energy.

\section{Sovereignty of Indonesia's Natural Resources:}

While Article 33 paragraph (5) emphasizes that: "Further provisions are regulated by law". Article 33 paragraph (3), (4) and (5) of the 1945 Constitution, there are important things that become the state's legal policy in the utilization natural resources and environmental management, among others, people's welfare become the philosophical and sociological basis for all activities and activities of utilizing natural resources to be used for people's welfare.

Utilization of natural resources is the responsibility of the state, where through the right to control the state, the state makes rules and policies on the use of the environment and natural resources. However, article 33 verses (3) and (4) can be interpreted that the prosperity of the people is prioritized, without ignoring the prosperity of the individual. Then the economy is based on economic democracy, prosperity for all people, therefore the branches of production which are important for the State and which control the lives of many people must be controlled by the State. If all this cannot be done, by the Indonesian state, the reins of production leadership will be controlled by the rulers and the people will only be spectators and be affected by the destruction of natural resources and the environment. Communities that have been living around forests, for example, have been disadvantaged and have become poorer, not because they are unskilled and do not know how to manage these forest resources, but because they are weak and have no power in local and national political constellations.

Various laws, such as Law Number 5 of 1960 concerning Basic Regulations on Agrarian Principles, Law Number 4 of 2009 concerning Minerba, and Law Number 41 of 1999 concerning Forestry and Law Number 18 of 2013 concerning Prevention and Eradication of Forest Destruction (UU P3H) based on the concept of the right to dominate the State which is a form of state power to take over the sovereignty of indigenous peoples over their land and natural resources. The holder of the right to control the State is the central government, in practice has issued management rights decisions, such as HPH, HTI, HGU as well as mining exploitation on national or foreign private companies, which has implications for serious violations of law and human rights. In connection with this issue, it is necessary to develop a national legal system construction based on local wisdom that can guarantee the protection of the rights of local communities to the legal, social, cultural and political systems that have been upheld so far, with the hope of preventing and minimizing natural resource conflicts in Indonesia. In this case Arief Sidharta proposed, the Indonesian national legal order must contain the following characteristics:

1. Nationalism and archipelago insight;

2. Able to accommodate legal awareness of regional ethnic groups and religious beliefs; 
3. To the extent possible in written and unqualified forms;

4. Be rational including efficiency rationality, reasonableness rationality (redelijkheid), principle rationality, and value rationality;

5. Procedural rules that guarantee transparency, which allows a rational review of the decision making process by the government;

\section{Responsive to the development of people's aspirations and expectations:}

Thus the realization of welfare and social justice is expected to cause a feeling of peace in the inner citizens of the community. With the maintenance of that peace, order will have strong roots, so that various social conflicts that occur in the country can be eliminated. Constitutionally, the 1945 Constitution of the Republic of Indonesia provides the basis for the "concept of state control" in mining management in Indonesia. The 1945 Constitution Article 33 paragraph (3) emphasizes that the earth, water and natural resources contained therein are controlled by the state and used for the greatest prosperity of the people. Considering that minerals and coal are natural resources contained in the earth are non-renewable natural resources, therefore their management needs to be carried out as optimally as possible, efficiently, transparently, sustainably, and environmentally sound, and fair in order to obtain the maximum benefits for the prosperity of the people as a whole. sustainable. In addition, mining development must adapt to changes in the strategic environment, both national and international. The main challenge faced by mineral and coal mining is the effect of globalization which drives democratization, autonomy regions, human rights, the environment, technological and information development, intellectual property rights and demands for increasing the role of the private sector and society.

As we know, minerals and coal contained in the mining jurisdiction of Indonesia as a gift from God Almighty, have an important role in meeting the needs of the lives of many people. That is why the management of mineral and coal mining must be controlled by the state in order to provide tangible added value to the national economy in an effort to achieve prosperity and welfare of the people in a just manner. Mineral and coal mining business activities have an important role in national economic growth and sustainable regional development. For this reason, mining management must be done wisely and wisely, so that there is balance and sustainability.

The concept of control by this state characterizes that the state of the Republic of Indonesia is a form of welfare state, in which the responsibility of the government is to create prosperity for its people. nature contained therein. The meaning of "mastery by the state" changes in meaning along with changes and challenges in the current era of globalization. The concept of control by the state leads to various forms of mining "exploitation" in Indonesia. What form is appropriate for use in mining operations, it must be in the corridor of the understanding of the concept of state control. The meaning of the concept of control by the state gave birth to the Government's authority to act "take care" and "regulate".

In the long journey during the management in the Republic of Indonesia, the authority of mining management experienced significant changes, especially when the reform era began in 2000. In the regime of Law No. 11 of 1967 concerning "Basic Mining Provisions", mining management authority with a centralistic nuance, where the Central Government (Minister) is given the authority to manage it. With the ongoing reformation era marked by the enactment of Law Number 22 Year 1999 concerning "Local Government", reversing the mining management system, which gave very broad authority to the Regional Government, especially Regencies / Cities based on the principle of broadest autonomy. Then the decentralized paradigm of Law Number 22 Year 1999 is only accommodated to Law Number 4 Year 2009 concerning "Mineral and Coal Mining". This very drastic change brought various challenges in its implementation.

The concept of control by this state characterizes that the state of the Republic of Indonesia is a form of welfare state, in which the responsibility of the government is to create prosperity for its people. nature contained therein. The meaning of "mastery by the state" changes in meaning along with changes and challenges in the current era of globalization. The concept of control by the state leads to various forms of mining "exploitation" in Indonesia. What form is appropriate for use in mining operations, it must be in the corridor of the understanding of the concept of state control. The meaning of the concept of control by the state gave birth to the Government's authority to act "take care" and "regulate".

In the long journey during the management in the Republic of Indonesia, the authority of mining management experienced significant changes, especially when the reform era began in 2000. In the regime of Law No. 11 of 1967 
concerning "Basic Mining Provisions", mining management authority with a centralistic nuance, where the Central Government (Minister) is given the authority to manage it. With the ongoing reformation era marked by the enactment of Law Number 22 Year 1999 concerning "Local Government", reversing the mining management system, which gave very broad authority to the Regional Government, especially Regencies / Cities based on the principle of broadest autonomy. Then the decentralized paradigm of Law Number 22 Year 1999 is only accommodated to Law Number 4 Year 2009 concerning "Mineral and Coal Mining". This very drastic change brought various challenges in its implementation.

The deteriorating condition of the Indonesian people, finally brought the Indonesian nation to the failure of longterm development as planned for 6 (six) Repelita. To overcome the deterioration, a plan for change and improvement in the state reform system (state reform) and improvements in the system of governance (administrative reform) in Indonesia. The amendment to the 1945 Constitution of the Republic of Indonesia brought significant changes to the constitutional system of the Republic of Indonesia. Changes in the system of government administration with the enactment of Law Number 22 of 1999 concerning Regional Government, which brought changes in the system of managing mining management in Indonesia. Until finally the enactment of Law Number 4 of 2009 concerning Mineral and Coal Mining, which provides policy directions tailored to the paradigm of regional autonomy as adhered to Law Number 22 of 1999.

Sovereignty is the full and highest power of a State to regulate its own territory without interference from the governments of other countries or international organizations. The concept of sovereignty as the highest authority contained in the 1945 Constitution in addition to having political meaning also has economic and social meaning as formulated in Chapter XIV of the 1945 Constitution which is deliberately given the title "National Economy and Social Welfare". Based on Article 33 paragraphs (2) and (3) in controlling national natural oil and gas / mineral resources, it is emphasized that the State of Indonesia as the representation of its citizens must truly represent the interests of all people who have the highest sovereignty or power over the economic resources of Indonesia's natural resources.

State power over natural resources is sourced from people known as the nation, to whom the authority or authority is given to regulate, administer, maintain, and supervise the utilization of all potential natural resources in all regions of Indonesia. Then the important components that must become the foundation of the development of the legal and political foundation of the management of natural oil and gas resources and national mineral rights that reflect the right to control by the State over oil and gas natural resources / minerals to realize national sovereignty are: a) Ownership of natural resources; b) Control by the State; c) The authority of State-Owned Companies in oil and gas / mineral and coal mining business up to the principle of cooperation with third parties (mainly with foreign parties).

Future models of natural resource management such as Oil and Gas and Minerba should prioritize the National Interest based on the spirit of nationalism in a broad sense, with the vision of realizing the State's objectives as contained in the opening of the 1945 Constitution paragraph 4 and must carry out the mission of building national independence and national energy security support sustainable national development. To realize this mission, the laws and regulations for the management of natural resources in the future need to be supported by "five pillars", namely: 1. Pancasila; 2. 1945 Constitution; 3. Homeland; 4. Politics of the partisanship of the Government of the Republic of Indonesia; and 5. Strengthening the Function of State Enterprises.

Future management of natural resources should be based on that ownership of natural resources is subject to mining legal provisions known as Mineral Rights, Mining Rights, and Mining Rights. Mineral power is the control of natural resources contained in an area of the country as an integral part of territorial sovereignty; mining authority is the authority in the regulation and supervision of the implementation of mining activities; and mining business authority is the authority to control and manage the business.

\section{References:-}

1. Bernard Arief Sidharta, Refleksi Tentang Struktur Ilmu Hukum: Sebuah Penelitian Tentang Fondasi Kefilsafatan Dan Sifat Keilmuan Ilmu Hukum Sebagai Landasan Pengembangan Ilmu Hukum Nasional Indonesia, (Bandung: Mandar Maju, 2000), Hal. 212

2. Fatma Ulfatun Najicha, Politik Hukum Pada Pembetukan Produk Hukum Perundang-Undangan Kehutanan. Kebumen: Intishar Publishing, 2019.

3. Gatot P. Soemartono, Hukum Lingkungan Indonesia, Sinar Grafika, Jakarta, 2004, hal 65 - 66 
4. Huala Adolf, Aspek-aspek Negara dalam Hukum Internasional, edisi revisi, Raja Grafindo Persada, Jakarta, 2002, hlm. 53-54

5. Jimly Asshiddiqie, Pokok-Pokok Hukum Tata Negara Indonesia, Bhuana Ilmu Populer, Jakarta,2007, hlm.148

6. Moh. Kusnardi, Pengantar Hukum Tata Negara Indonesia, Sastra Hudaya, Jakarta, 1976, hlm. 123.

7. Parry and Grant, et all., Encyclopedic Dictionary of International Law, Oceana Publication Inc., New York, 1986. hlm. 290.

8. Peter Mahmud Marzuki, Penelitian Hukum, Prenada Media, Cetakan Ke-6, 2010, Jakarta, hlm. 93-94.

9. R. Wiratno dkk.,Ahli-Ahli Pikir Besar tentang Negara dan Hukum, PT. Pemabngunan, Jakarta,1985, hlm. 176.

10. Soediman Kartohadiprodjo, Pancasila Sebagai Pandangan Hidup Bangsa Indonesia, Bandung, 2011, hlm. xi

11. Starke, JG., Introdiction to International Law, 10th edition, Butterworth, London, 1989, hlm.121

12. Suyitno Patmosukismo, Migas Politik, Hukum dan Industri, Fikahati Aneska, Jakarta, 2011,hlm. 157

13. Tri Hayati, Perizinan Pertambangan di Era Reformasi Pemerintahan Daerah, Studi tentang Perizinan Pertambangan Timah. Jakarta : Badan penerbit Fakultas Hukum Universitas Indonesia, 2012, hal.62. 